\title{
Moral Exclusion and the Justification of U.S. Counterterrorism Strategy: Bush, Obama, and the Terrorist Enemy Figure
}

\author{
Andrew Pilecki, Jonathan M. Muro, Phillip L. Hammack, and Carley M. Clemons \\ University of California, Santa Cruz
}

\begin{abstract}
We analyzed speeches made by Presidents George W. Bush and Barack Obama to reveal how each president justified post-9/11 U.S. counterterrorism policy. Our analysis revealed that both Bush and Obama delegitimized terrorists by distinguishing them from other legitimate political categories, by emphasizing the morally condemnable and apolitically motivated form of violence they inflict. This vilification facilitated the portrayal of terrorism as a problem transcending national interest. U.S. counterterrorism strategies were thus justified as a necessary and rational solution to the scope and severity of the terrorist threat. This study illustrates how the "complex discursive accomplishment" of moral exclusion (Tileagă, 2007) emerges within presidential rhetoric to frame the relations among groups and legitimizing particular actions, namely, harsh antiterror measures (e.g., indefinite detention, preemptive war, and torture). Our study also illustrates the similarities between how Bush and Obama have talked about terrorism, thus indicating the overall naturalization of a "war on terrorism" discourse following the $9 / 11$ attacks.
\end{abstract}

Keywords: George W. Bush, Barack Obama, counterterrorism, discourse analysis, war on terrorism

On September 30, 2011, Anwar al-Awlaki, a U.S. citizen, was killed in Yemen by a CIA drone strike (Greenwald, 2013a). This event marked the first time since the Civil War that the U.S. government executed a citizen as a war-time enemy without trial (Mazzetti, Savage, \& Shane, 2013). Al-Awlaki had been a target for scrutiny for over a decade for his associations with militant groups, and had been linked to the Fort Hood shooting and the attempted bombing of a Northwest Airlines flight in December 2009. It was determined that the drone strike would be lawful, given al-Awlaki's affiliation with Al Qaida, the threat he posed to

Andrew Pilecki, Jonathan M. Muro, Phillip L. HaMMACK, and CARley M. Clemons, University of California, Santa Cruz.

A PREVIOUS VERSION of this article was presented at the 35th annual meeting of the International Society of Political Psychology in Chicago, Illinois. We acknowledge the assistance of R. Andrew Gibson and Elsamarie Corradetti in the preparation of this article.

CORRESPONDENCE CONCERNING THIS ARTICLE should be addressed to Andrew Pilecki, Department of Psychology, University of California, 1156 High Street, Santa Cruz, CA 95064. E-mail: apilecki@ucsc.edu
U.S. citizens, and the fact that capture would likely be infeasible (Greenwald, 2013a; Mazzetti et al., 2013). Samir Khan, who was also a U.S. citizen, was killed as collateral damage in the same strike despite not being previously deemed a justified target (Mazzetti et al., 2013). On October 14, 2011, al-Awlaki's 16-year-old son-also an American citizen - was killed by yet another drone strike targeting an Egyptian Al Qaeda operative (Greenwald, 2013a). Over a 2-week time period, the U.S. government, in the name of combating terrorism, was responsible for the deaths of three of its citizens, only one of whom had any confirmed ties to suspected terrorist organizations.

U.S. counterterrorism policy has undergone dramatic changes since the September 11, 2001 attacks on the World Trade Center and the Pentagon. Actions such as preemptive war, the use of "enhanced" interrogation techniques, the indefinite detention of terrorism suspects, and the use of targeted killings by armed drones have all been deployed in the "war on terrorism" to combat terrorists and make the country - and the world, for that matter-safer. Many have argued that these methods not only violate domestic and international law but also constitute 
a war on the very ideals that define the United States of America (Mayer, 2009). Nevertheless, public support for these measures remains high. For example, 10 years after the September 11th attacks, $56 \%$ of Americans supported President Bush's response to the attacks, and $76 \%$ believed that the torture of terrorism suspects could be justified in order to obtain information (Pew Research Center, 2011).

How have U.S. counterterrorism efforts become so palatable to the public? Although research on President Bush's rhetoric concerning the war on terrorism has been extensive (e.g., Esch, 2010; Jackson, 2005, 2007; Kinsella, 2005; Lazar \& Lazar, 2004; Leudar, Marsland, \& Nekvapil, 2004; Sowińska, 2013), there has been little inquiry on President Obama's rhetoric (for a notable exception, see McCrisken, 2011) regarding terrorism and U.S. counterterrorism policy, despite the fact that many counterterrorism tactics (e.g., indefinite detention, the use of drones for targeted killing) have persisted during his administration. To address this issue, we examined the moral discourse emerging from speeches made by President George W. Bush and President Barack Obama on the topic of terrorism to reveal the ways in which U.S. counterterrorism policy was continually justified in the decade following the 9/11 attacks. We were particularly interested in how Bush and Obama framed terrorists as a distinct category of political actors that were unworthy of moral and just treatment.

\section{Discourse, Mind, and Society}

Our study is rooted in a discursive theoretical framework that recognizes the relationship between mind and society and the mediating role that language serves. Social scientists have long recognized the power of language to shape thought (e.g., Sapir, 1921; Whorf, 1956) and to mediate our experience of the material world through a process of symbolic interaction (e.g., Blumer, 1969; Mead, 1934). As a form of tool use, language guides our understanding of the social world through practical activity ( $\mathrm{Vy}-$ gotsky, 1934/1962). Language is not neutral vis-à-vis politics and is always situated in relation to a particular "verbal-ideological" community (Bakhtin, 1981; Hammack \& Toolis, in press; Volosinov, 1929/1973). Language assumes a coherent form when it is organized as a story that provides a sense of meaning (e.g., Bruner, 1990), and this meaning is imbued with implications for action or reaction (Parker, 1990).

The discursive turn in social and political psychology began in the 1980s and has flourished since (e.g., Billig, 2012; Potter, 1996; Potter \& Wetherell, 1987). Recognition of the centrality of discourse in psychological life is rooted in the linguistic mediation thesis, a longrecognized perspective in the social sciences that language is the tool through which social and psychological life is dynamically coconstituted (see Hammack \& Pilecki, 2012; Tileagă, 2013). According to the linguistic mediation thesis, our encounter with the material world achieves coherence through systems of signification, namely, language in its organized form (Hammack \& Pilecki, in press). Language is performative (Austin, 1962) and evokes a cognitive, affective, or behavioral response (Hammack \& Pilecki, in press).

In the perspective of discursive social psychology, language is central to our understanding of concepts and categories (e.g., Edwards, 1991). The rhetoric used to describe persons, concepts, events, and categories assumes an argumentative form (Billig, 1996), always oriented toward some form of interest with regard to the matrix of social categories (Hammack, in press). Leaders and figures of authority, such as presidents, shape the popular understanding of concepts and categories through rhetoric that situates subjects in a larger moral framework (Hammack, in press).

The purpose of our study was to examine terrorism-related discourse that emerged among speeches given by Presidents George W. Bush and Barack Obama. We were particularly interested in comparing and contrasting how each president defined who the "terrorists" were, what they seek to do, and why they seek to do it. In doing so, we sought to reveal how the category of "terrorist" was framed as a special case within the general category (cf. Billig, 1996) of those who would otherwise be afforded moral and just treatment. What makes, in other words, the problem of terrorist violenceand, by implication, those who employ it-so unique that it requires certain, otherwise extreme, solutions to address it? To address this question, we focused specifically on the moral content present within Presidents Bush's and 
President Obama's speeches on the subject of terrorism and the U.S. counterterrorism response.

\section{The Discourse of Terrorism}

Although our purpose is to examine the moral basis upon which U.S. counterterrorism policy has been legitimized following the September 11,2001 attacks, it is important to first recognize that this area of research is not without precedent. Numerous studies have analyzed the political rhetoric of the war on terrorism and have illustrated the various means through which President Bush and his allies legitimized the war on terrorism. There has been less of an effort, however, in extending this type of analysis to President Obama.

Research has examined the effect that the label of "terrorist" has on people's attitudes toward the appropriateness of certain counterterrorism measures (see also Bhatia, 2005). In a study conducted with Philippine and Malaysian samples, Montiel and Shah (2008) found that the effect of the "terrorist" versus "freedom fighter" was moderated by in-group status. Nondominant group members were more likely to sympathize with those described as freedom fighters compared with dominant group members. Dominant group members, however, viewed those labeled as freedom fighters less favorably than those labeled as terrorists. Elaborating on this finding, Golec de Zavala and Kossowska (2011) found that the effect of framing terrorists as either soldiers or criminals was moderated by the social, political, and ideological position of the listener. Participants high in right-wing authoritarianism were the most likely to endorse criminal methods of counterterrorism when terrorists were framed as criminals.

Regarding the emotional content of terrorism-related rhetoric, De Castella and McGarty (2011) examined the use of fear and anger appeals in speeches made by President Bush and British Prime Minister Tony Blair between September 2001 and May 2003. Although present in a majority of speeches, De Castella and McGarty (2011) found that the frequency of these emotional appeals fluctuated over time, with fear being especially prominent in the period immediately prior to the U.S.-led invasion of Iraq in March 2003 (see also De Castella, Mc-
Garty, \& Musgrove, 2009). These findings indicate that rather than a sustained campaign of "fear mongering" (cf., Jackson, 2005), Bush and others used emotional appeals selectively, with fear emerging more during times of political tension and decreased support for U.S.-led policies (De Castella et al., 2009). Although there is little evidence to suggest that fear appeals, for example, increased fear among the general public, De Castella and McGarty (2011) contend that their findings illustrate that emotion is a rhetorical strategy that is deployed selectively, either to mobilize support or constrain debate regarding public policy.

Jackson (2007) argues that not only was fear of "sudden violent death" by terrorist violence used within rhetoric, but normalization and legitimization of the war on terrorism was accomplished through the construction and dissemination of various narrative structures (see also Esch, 2010; Jackson, 2005). One dominant narrative trope was the depiction of the war on terrorism as a "new war" that required new strategies and new means to fight the enemy (e.g., enhanced interrogation). From this narrative framework, policies construed as protective, albeit contradictory to U.S. cultural norms and values, were developed and "normalized." Other narratives and discursive frames to legitimize the war on terrorism have been identified as well. For example, depictions of the war on terrorism as a defense of civilization against barbarism (Collet, 2009; Jackson, 2005; Kinsella, 2005) and as a defense of universal values (Lazar \& Lazar, 2004; Sowińska, 2013) have been used to distinguish the United States and its allies from terrorists and provide the eventual justification for violence against the latter (see also Leudar et al., 2004).

Overall, the research reviewed has identified various components of the political rhetoric used to legitimize the war on terrorism and the counterterrorism tactics found therein. Our study aimed to enrich this body of research in two ways. First, previous research has examined the role moral discourse in legitimizing the war on terror. Lazar and Lazar (2004) and Sowińska (2013), for example, examined how the war on terrorism was justified on the basis that it defended universal moral values. Building on this research, our study sought to illustrate how moral discourse was employed in the construction of a morally 
excluded (Opotow, 1990) social category portrayed as undeserving of moral consideration (see Tileagă, 2007) Second, there has been a lack of research analyzing terrorism-related rhetoric made by President Obama. We find this lack of attention paid to the Obama administration especially troubling, as many controversial counterterrorism policies (e.g., domestic surveillance, the continued operation of the Guantanamo Bay prison camp) have remained in place during his term in office. McCrisken (2011), as a notable exception to this gap within the literature, analyzed speeches made by Barack Obama-both as presidential candidate and as president - and found little deviation from the type of war on terror discourse established by his predecessor. Our study wished to contribute to this burgeoning line of inquiry into political discourse.

\section{The Terrorist as a Morally Excluded Category}

Our study was interested in how terrorists were distinguished along a moral basis such that extreme counterterrorism measures were considered to be both necessary and justified. There is a rich theoretical literature within social psychology describing the mechanisms through which groups are deemed either worthy or unworthy of moral treatment. Opotow (1990) contends that those who are perceived to be outside one's scope of justice are not extended considerations of justice and fairness. Elaborating upon this framework, Bar-Tal (1990; see also Bar-Tal \& Hammack, 2012) proposed that the delegitimization of groups - namely, the belief that a group has violated fundamental human norms and values, and is thus no longer considered part of the community of "acceptable" groups - facilitates intergroup violence (BarTal \& Hammack, 2012; Halperin, Bar-Tal, Sharvit, Rosler, \& Raviv, 2010; Oren, Rothbart, $\&$ Korostelina, 2009). Using a discursive perspective, Tileagă (2007) argues that such "ideologies of moral exclusion" are rooted in a moral discourse of place-appropriate conduct, the proposed transgression of which is employed to justify prejudice and discrimination (Tileagă, 2005, 2006, 2013).

The essence of moral exclusion, particularly from a discursive perspective, is the demarca- tion of a particular social category - or categories - from those otherwise perceived to be worthy or deserving of moral consideration. Moral exclusion is thus a form of particularlization (Billig, 1985, 1996), in which a group is treated as a special case within a much larger category. This process of social discrimination is often couched within a moral discourse, as it is through the moral condemnation of another's behaviors, values, or traits that the derogation of an out-group as nonhuman or somehow less worthy is fulfilled (Graumann, 1998). The discourse of moral exclusion, moreover, occurs within a larger rhetorical context of justification and criticism (Billig, 1996; Condor, Tileagă \& Billig, 2013). Hence, the proposed treatment of a group as a special case serves the purpose of justifying how that group is treated-thereby preserving the moral status of the in-groupwhile counteracting rival discourses that may question this type of discrimination or the moral status of the in-group.

Tileagă's $(2005,2006)$ research on middleclass Romanian views toward Romanies illustrates the "complex discursive accomplishment" (Tileagă, 2007, p. 732) of moral exclusion. Interviewees in these studies would frequently describe how Romanies "lived in dirt" and were otherwise ungrateful for the government services that they received. Violating the normative standards of civilized society, Romanies were thus depicted as a category of people that were incongruous with the moral order characterizing civilized society. Positioned outside the boundaries of society, Romanies became appropriate targets of prejudice and discrimination. Given their uniquely problematic nature, Romanies were also framed as a social problem requiring a "solution" that implied actions that existed outside the bounds of democratic and moral procedure (see also Tileagă, 2013).

Our study examined how Presidents Bush and Obama engaged in the "complex discursive accomplishment" (Tileagă, 2007, p. 732) of moral exclusion with respect to terrorism. Graumann (1998) argues "that it is primarily and sometimes exclusively by moral discourse that we separate from and exclude others" (p. 47). We were therefore interested in how each president rhetorically constructed the category of "terrorist" as incongruous with the moral order (Tileagă, 2007) and thus a special case toward 
which normal standards of treatment (e.g., due process) no longer applied. We were also interested in how U.S. counterterrorism strategy was normalized within presidential discourse, that is, the rhetorical process through which terrorists were morally excluded and thus framed as a unique problem requiring an equally unique response (cf. Edelman, 1988).

\section{Method}

\section{Data Corpus}

The criteria used for obtaining the speeches consisted of searching the White House's official Web site and news media Web sites (i.e., Fox News, NPR) for speech transcripts from both President Barack Obama and thenPresident George W. Bush relating to the war on terrorism. Once a speech was found, we conducted a word search for variations of the word "terror" ("terrorism," "terrorist," and "counterterrorism"). If the speech contained at least one of these variations, it was included in our corpus for analysis. A total of 20 speeches, 11 from George W. Bush and 9 from Barack Obama, were collected for analysis (see Table 1).

\section{Analytic Framework}

Our analysis was informed by discursive psychology, which views language as a form of action that is shaped by the social context from which it emerges, as well as serves a constitutive role in shaping that context (Edwards \& Potter, 1992; Hammack \& Pilecki, in press; Potter \& Wetherell, 1995). Social categories, likewise, are rhetorical constructions rather than reflections of the objective conditions of reality (see Edwards, 1991; Billig, 1996). The boundaries of category membership, and the meaning found therein, are, in essence, negotiable. Defining the contours of social categories is thus a powerful means of mobilizing political support (Reicher \& Hopkins, 1996, 2001a, 2001b) as well as reifying asymmetrical relations among groups (Reicher, 2004).

From this theoretical framework, we employed an iterative approach to our discursive analysis. As in previous research using this strategy (Gibson, 2012; Hammack, 2010; Sani \& Reicher, 1998, 1999), we conducted a series
Table 1

Corpus of Speeches

\begin{tabular}{|c|c|c|}
\hline Date & Speaker & Description \\
\hline September 12, 2001 & Bush & $\begin{array}{l}\text { Address to the Nation: } \\
\text { 9/11 Terrorist Attacks }\end{array}$ \\
\hline January 29, 2002 & Bush & $\begin{array}{l}\text { State of the Union } \\
\text { (SOTU) }\end{array}$ \\
\hline January 20, 2004 & Bush & SOTU \\
\hline February 2, 2005 & Bush & SOTU \\
\hline January 31, 2006 & Bush & SOTU \\
\hline September 6, 2006 & Bush & $\begin{array}{l}\text { Official Remarks on } \\
\text { Terrorism }\end{array}$ \\
\hline January 23, 2007 & Bush & SOTU \\
\hline July 24, 2007 & Bush & $\begin{array}{l}\text { Official Remarks on } \\
\text { War on Terror }\end{array}$ \\
\hline January 28, 2008 & Bush & SOTU \\
\hline March 19, 2008 & Bush & $\begin{array}{l}\text { Official Remarks: War } \\
\text { on Terror }\end{array}$ \\
\hline January 15,2009 & Bush & Farewell Address \\
\hline March 27, 2009 & Obama & $\begin{array}{l}\text { Official Remark: New } \\
\text { War Strategy }\end{array}$ \\
\hline May 21, 2009 & Obama & $\begin{array}{l}\text { Official Remarks on } \\
\text { Osama Bin Laden }\end{array}$ \\
\hline December 1, 2009 & Obama & $\begin{array}{l}\text { Address to the Nation: } \\
\text { War on Terror }\end{array}$ \\
\hline December 28, 2009 & Obama & $\begin{array}{l}\text { Address to the Nation: } \\
\text { Terrorist Attack }\end{array}$ \\
\hline January 7, 2010 & Obama & $\begin{array}{l}\text { Official Remark on } \\
\text { Preventing Terrorism }\end{array}$ \\
\hline May 2, 2011 & Obama & $\begin{array}{l}\text { Official Remarks on } \\
\text { Preventing Terrorism }\end{array}$ \\
\hline September 11, 2012 & Obama & $\begin{array}{l}\text { Pentagon 9/11 Memorial } \\
\text { Service }\end{array}$ \\
\hline September 12, 2012 & Obama & $\begin{array}{l}\text { Deaths of U.S. Embassy } \\
\text { Staff in Libya }\end{array}$ \\
\hline May 23, 2013 & Obama & $\begin{array}{l}\text { Guidelines for Drone } \\
\text { Strikes Against U.S. } \\
\text { Citizens }\end{array}$ \\
\hline
\end{tabular}

Note. Speeches cited in the manuscript that were not included in the corpus of data are listed in the References.

of close readings of speeches included in our corpus. We focused our analysis on the moral content that Presidents Bush and Obama used in describing terrorism and those who engage in it. In doing so, we sought to reveal how the category of "terrorist" was rendered morally abject and thus a legitimate target for treatment that would otherwise seem immoral or undemocratic. Regarding the latter, we also sought to reveal how U.S. counterterrorism strategy was framed as a normative, rational solution to the size and scope of the threat that terrorists purportedly posed to the United States and the global community (see Edelman, 1988; Tileagă, 2007). 


\section{Results}

Our analysis revealed a common discourse regarding terrorism and counterterrorism within the speeches we analyzed. Presidents Bush and Obama accomplished the "complex discursive accomplishment" (Tileagă, 2007, p. 732) of moral exclusion by framing terrorist violence as both morally condemnable and apolitical. Terrorism, as it was described in these speeches, represented violence and destruction for its own sake. The political impetus behind terrorism, moreover, was not acknowledged beyond its goal to destroy commonly held moral values (e.g., freedom). The "terrorist" was therefore distinguished as a particularly evil - and illegitimate - category of political actor that posed an omnipresent threat to both U.S. interests and the global community. Given the scope and severity of the problem that terrorists posed, the only rational solution, as it was asserted within the speeches given by Bush and Obama, was to implement counterterrorism strategies of equivalent scope and severity. It is in this manner that the greatest excesses of the post-9/11 response to terrorism were justified.

\section{Distinguishing the Terrorist Category}

The discourse outlined in Figure 1 is rooted in the fundamental claim that terrorist violence is an especially morally condemnable form of harm. This claim is rooted in the presumed innocence and noncombatant status of its vic-

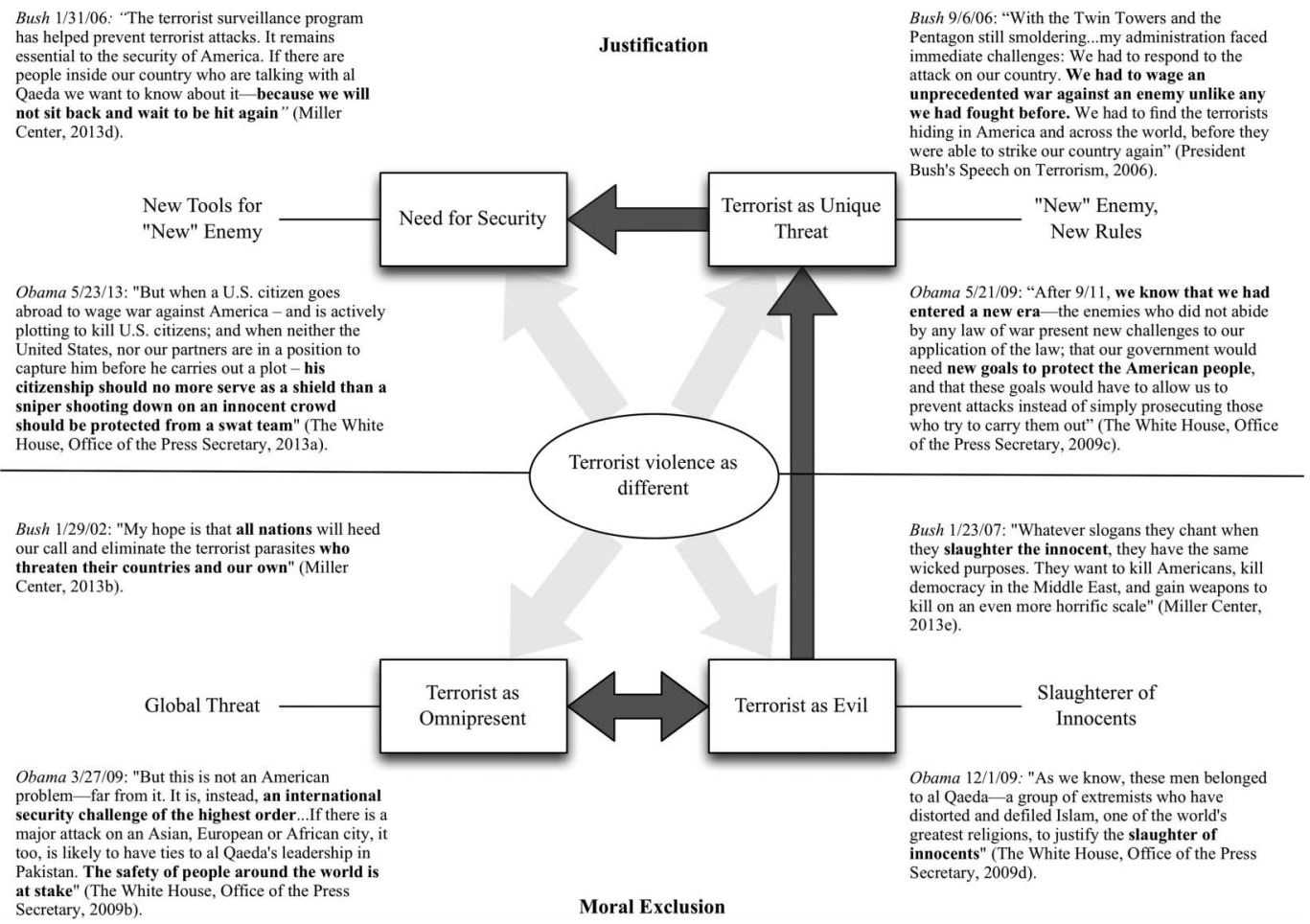

Figure 1. Terrorism-related rhetoric by President Bush and President and Obama was rooted in the fundamental claim that terrorism was a particularly immoral, apolitical form of violence. This claim facilitated the distinction of the terrorist as a morally excluded category. Framed as both evil and a threat to commonly held values, terrorism was construed as a global threat, rather than a threat particular to the United States and its interests. Constructed as an omnipresent and grave threat, the justification for the U.S. response to the problem that terrorists posed was rooted in two claims: first, that terrorists represented a "new" threat, and second, that because they constituted a new threat, "new" tools were needed to increased security and end the terrorist threat. 
tims, which was emphasized and repeated by both Bush and Obama to distinguish terrorist violence from other forms of political violence. Terrorists are evil, in other words, because they senselessly slaughter and murder innocent men, women, and children. This point was made clear in President Bush's farewell address on January 15,2009 , when he declared that "good and evil are present in the world and between the two of them there can be no compromise. Murdering the innocent to advance an ideology is wrong every time, everywhere. (Miller Center, 2013a)". The presumption that targets of terrorist violence are innocent extends to those who, by definition, are not civilians and thus cannot be victims of terrorism: "No enemy is more ruthless in Iraq than al-Qaeda. They send suicide bombers into crowded markets; they behead innocent captives and they murder innocent troops" (The White House, Office of the Press Secretary, 2007). Despite Iraq being an active war zone at the time, the violence inflicted by al-Qaeda in Iraq against coalition troops is grouped with attacks on distinctly nonmilitary, and thus "innocent," targets (marketgoers and captives).

Terrorist violence was often framed in apolitical terms. Rather than pursuing a specific political agenda, terrorist violence, according to Bush and Obama, is motivated purely by hatred and a base desire to kill. Within this frame, terrorist violence is not a means to an end; rather, it is sought after as an end in itself. In his State of the Union Address on January 29, 2002, President Bush declared that "our enemies send other people's children on missions of suicide and murder. They embrace tyranny and death as cause and creed." (Miller Center, 2013b) When the political objectives of terrorist actors are mentioned, it is generally in terms of their hostility to Western values, which are often depicted in universalist terms - particularly by President Bush. Human freedom is antithetical to terrorists and their aims. "The advance of liberty is opposed by terrorists and extremists," Bush said in his January 28, 2008, State of the Union Address, "evil men who despise freedom, despise America, and aim to subject millions to their violent rule." (Miller Center, 2013f) Beyond murder, then, the only other objective of terrorists was to destroy the universal moral good that is human freedom.
Although Obama had made steps to contextualize the conflict between the United States and groups like al Qaeda by addressing U.S. foreign policy and its history with the "Muslim world" (see (The White House, Office of Press Secretary, 2009a)), Obama did not reject the characterization of terrorists as evil. "And where terrorists offer only the injustice of disorder and destruction," Obama declared in a speech on May 21, 2009, "America must demonstrate that our values and our institutions are more resilient than a hateful ideology." Like Bush, Obama here references terrorists with terms like "disorder" and "destruction" while framing their political objectives as encompassing a "hateful ideology." (The White House, Office of the Press Secretary, 2009c) This apolitical framing of terrorist actors emerged in President Obama's speech on the death of Osama bin Laden:

[bin Laden] was a mass murderer who offered a mes-
sage of hate-an insistence that Muslims had to take
up arms against the West, and that violence against
men, women and children was the only path to change.
He rejected democracy and individual rights for Mus-
lims in favor of violence extremism; his agenda fo-
cused on what he could destroy - not what he could
build. (The White House, Office of the Press Secretary,
2011)

Bin Laden is thus framed in terms of the terrorist-as-evil construction that emerged under Bush. Driven by hate and a desire to kill, bin Laden is portrayed as the antithesis of universal (i.e., Western) values and offering only an "extremist" agenda of destruction.

Because of their hostility to universal values and their desire to harm innocent people, both Bush and Obama framed terrorists as threats to the global community and not just the United States. This framing served the dual purpose of morally excluding those labeled as terrorists from the global community as well as rallying international support for U.S. counterterrorism policies. "History has called America and our allies to action," declared President Bush in his January 29, 2002 State of the Union Address, "and it's both our responsibility and our privilege to fight freedom's fight." (Miller Center, 2013b) This statement emphasizes the threat to all freedom-loving nations that terrorists pose. As a value under threat, such nations have the moral obligation to ally themselves with the United States and defend freedom. 
Echoing this narrative framework, President Obama, in describing the terrorist threat, remarked in March 27, 2009 speech that, "what's at stake at this time is not just our own security-it's the very idea that free nations can come together on behalf of our common security." (The White House, Office of the Press Secretary, 2009b) As with Bush, Obama juxtaposes the terrorist enemy figure against a community of "free nations" from which they are excluded. This community must rally together to face this common threat-defined by the United States-for the sake of preserving their common security. In doing so, they lend implicit support to U.S. counterterrorism efforts.

\section{"New Tools" for a "New" Threat}

In light of the level and scope the terrorist threat poses, what can be done to safeguard the public? U.S. counterterrorism policy, which has featured - and, in some respects, still feature"enhanced" interrogation, domestic surveillance, and drone strikes in foreign countries, was morally justified by Presidents Bush and Obama on the basis that it makes the public safer. This justification was rooted in two fundamental claims: first, that terrorists constitute a "new" threat; and second, that because they represent a new threat, "new tools" are needed to make the United States - and the worldmore secure (see the top portion of Figure 1).

The depiction of terrorism as a new, unprecedented threat by Bush has been explored elsewhere (see Jackson, 2005, 2007). "Mr. Speaker, Vice President Cheney, members of Congress, distinguished guests, fellow citizens, as we gather tonight," President Bush opened his January 29, 2002 State of the Union Address, "our nation is at war, our economy is in recession, and the civilized world faces unprecedented dangers." (Miller Center, 2013b) The terrorist enemy figure described by Bush is depicted as both a threat to the civilized world and as a new political actor on the world stage. Regardless of the persistence of incidents of international terrorism throughout the 20th century (Hoffman, 2006), the asserted "newness" of those who carried out the September 11, 2001 attacks buttressed the subsequent claim that the U.S. government required "new tools" to fulfill its fundamental duty of protecting the nation. Obama's narrative of the government's response to the September 11, 2001 attacks in a speech given on May 21, 2009, illustrates this argument:

\begin{abstract}
After 9/11, we knew we entered a new era-the enemies who did not abide by any law of war presented new challenges to our application of the law; that our government would need new tools to protect the American people, and that these tools would have to allow us to prevent attacks instead of simply prosecuting those who carry them out. (The White House, Office of the Press Secretary, 2009c)
\end{abstract}

Although his May 21, 2009 speech became noteworthy for its explicit repudiation of Bushera counterterrorism policies, ${ }^{1}$ Bush-era rhetoric was nevertheless reflected in Obama's narrative, in that the perpetrators of the 9/11 attacks were depicted as a "new" kind of threat requiring "new" tools to fight them.

The argument that "new" tools were necessary to safeguard the public was often predicated on the supposed failures of the "old" methods that the government had at its disposal that led to the September 11, 2001 attacks. This line of argument is alluded to in the closing of Obama's statement, namely, that the government would need "new tools to protect the American people" because these would allow the prevention of future terrorist attacks. Obama thus contrasts the proactive strategy of prevention with the more passive legal approach ("instead of simply prosecuting those who carry them out") that can only be implemented after an attack has been attempted. The supposed failure of the traditional legal system to deal with terrorism had been emphasized earlier by President Bush when he declared in his January 20, 2004 State of the Union Address that "after the chaos and carnage of September the 11th it [was] not enough to serve our enemies legal papers. The terrorists and their supporters declared war on the United States and war is what they got." (Miller Center, 2013c)

In this statement, Bush directly points to the inadequacies of the former juridical approach to

\footnotetext{
${ }^{1}$ For example, Obama declared in this speech that "to protect the American people and our values, we've banned enhanced interrogation techniques. We are closing Guantanamo. We are reforming military commissions and will pursue a new legal regime to detain terrorists. We are declassifying more information and embracing more oversight of our actions and we're narrowing our use of the state secrets privilege. These are dramatic changes that will put our approach to national security on a surer, safer, and more sustainable footing."
} 
counterterrorism and clearly places counterterrorism within a war discourse (see Crawford, 2003).

The use of a war framework rationalized counterterrorism tools that would otherwise be unavailable under the former legal framework. Justifying the use of enhanced interrogation (e.g., "waterboarding"), President Bush stated in a September 6, 2006 speech, "I can say that questioning the detainees in this program has given us information that saved innocent lives by helping us stop new attack-here in the United States and across the world." (President Bush's Speech on Terrorism, 2006)

Given the emphasis on preventing new attacks, rather than simply prosecuting those who plot them, terrorists are referred to in martial terms. Rather than suspects, they are "detainees" or "unlawful combatants" (Kinsella, 2005). Legal frameworks and international standards of justice are superseded by the need to secure the public, a hierarchy of values made clear by President Bush's declaration during his January 20, 2004 State of the Union Address: "America will never seek a permission slip to defend the security of our country." (Miller Center, 2013c)

The moral supremacy of security above all other values also emerged in President Obama's justification for the drone strike that killed Anwar Awlaki: "I would have detained and prosecuted Awlaki if we captured him before he carried out a plot," President Obama remarked in a speech given on May 23, 2013, "But we couldn't. And as President, I would have been derelict in my duty had I not authorized the strike that took Awlaki out." (The White House, Office of the Press Secretary, 2013a) Because Awlaki was a terrorist, and like all terrorists, "he was continuously trying to kill people," due process and legal considerations are only adhered to as a matter of convenience. As made evident by Obama, the otherwise extrajudicial killing of a U.S. citizen in a foreign country was nonetheless morally justified in the name of national security.

\section{Discussion}

The purpose of this study was to examine terrorism-related rhetoric in speeches made by Presidents George W. Bush and Barack Obama. We sought specifically to identify how moral discourse was employed by each president to define who the terrorists were and to justify measures to stop them. Our study revealed how Presidents Bush and Obama employed moral discourse to achieve the "complex discursive accomplishment" of moral exclusion (Tileagă, 2007, p. 732). The moral exclusion of the "terrorist" was accomplished by framing the harm that terrorists inflict as especially morally objectionable. The "problem" (i.e., threat) of terrorism was amplified, moreover, such that drastic solutions (i.e., new counterterrorism "tools") were deemed necessary in order to safeguard the public (cf., Edelman, 1988). These new tools (e.g., enhanced interrogation, indefinite detention, domestic surveillance) were morally justified on the basis of the security that they afforded the country as well as the global community.

As illustrated in Figure 1, both Bush and Obama distinguished terrorists as "evil" and their violence as particularly morally objectionable. Statements emphasizing the innocence of the victims, as well as their apolitical motivations (e.g., hatred), buttressed this characterization. These claims served to distinguish the terrorist category from other political actors along a moral basis. Due to their violation of seemingly universal moral values regarding life, liberty and justice, terrorists were construed as global threat that demanded a global response. We interpreted this framing as an attempt to rally international support for U.S. counterterrorism policies (Lazar \& Lazar, 2004).

Both Bush and Obama accomplished the justification of extreme counterterrorism measures via a rhetorical appeal to the "newness" of the terrorist threat and the necessity of "new" tools to protect the public. Depicted as evil, terrorists were portrayed as a new, unprecedented threat to the United States, in particular, and the world, in general (see Jackson, 2005). Given the unprecedented nature of the threat, both Bush and Obama acknowledged the failures and inadequacies of the "old" ways of dealing with terrorism, which was generally through the legal system. Moving counterterrorism from a juridical framework to a war framework (Crawford, 2003), "new" tools were argued to be necessary to safeguard the public. These new tools, for example, enhanced interrogation for Bush and drone strikes for Obama, were justified on the basis that they prevented terror attacks and increased security. 
The overall similarity we observed between the conservative-leaning Bush and the liberalleaning Obama thus reaffirms the findings of McCrisken (2011). In other words, despite notable statements to the contrary, President Obama largely maintained the war-on-terrorism discourse that emerged during the Bush administration. We interpret this finding in two ways. First, the similarity we observed between the terrorism-related rhetoric of President Bush and President Obama may be evidence of the overall "naturalization" of post-9/11 terrorism discourse. Second, if the oft-cited adage that "politics stop at the water's edge" (Vandenberg, 1952 ) is true, partisan differences in moral discourse are less likely to emerge a priori in presidential rhetoric on foreign policy matters. We close our discussion by addressing the implications of our study for peace psychologists interested in the consequences of U.S. counterterrorism efforts.

\section{The Naturalization of Terrorism Discourse: The Case of President Obama's Ambivalence}

On June 5, 2013, journalist Glenn Greenwald of The Guardian revealed that the National Security Agency (NSA) had been collecting mobile-phone records of U.S. citizens (Greenwald, 2013b). Subsequent disclosures sourced to former NSA contractor Edward Snowden revealed that this type of domestic surveillance extended to the collection of data from Internet servers in conjunction with companies like Google, Apple, and Facebook (Greenwald \& MacAskill, 2013). This program, called Prism, grew out of legislation during the Bush Administration that made Internet and telecommunication companies immune from prosecution for their work with the NSA (Greenwald \& MacAskill, 2013). In the wake of the controversy that arose following the reports about the NSA's activities, President Obama defended the program to reporters by remarking,

\footnotetext{
It's important to recognize that you can't have $100 \%$ security and also then have $100 \%$ privacy and zero inconvenience. ... What I can say is that in evaluating these programs, they make a difference in our capacity to anticipate and prevent possible terrorist activity. (The White House, Office of the Press Secretary, 2013b)
}

When asked about his thoughts about the NSA in an interview with CNN nearly a month after Obama's statement, former President Bush remarked that, regarding the relationship between security and privacy, "There needs to be a balance, and as [President Obama] explained, there is a proper balance" (Mullen, 2013).

President Obama explicitly challenged the counterterrorism policies of the Bush administration in his May 21, 2009 speech in which he notably pledged to close the prison camp in Guantanamo Bay and renounced the use of torture. When compared with our findings, these pronouncements highlight the overall ambivalence of President Obama's rhetoric on terrorism and counterterrorism. That is, while challenging some of the most controversial counterterrorism measures, we found that Obama retained much of the terrorism discourse characteristic of the Bush administration (see McCrisken, 2011). For example, whereas Obama stated on January 7, 2010, that "we are at war against al Qaeda . . . and we will do whatever it takes to defeat them," he noted 3 years later on May 23, 2013, that "we must define the nature and scope of this struggle or else it will define us, mindful of James Madison's warning that 'No nation could preserve its freedom in the midst of continual warfare." Obama thus recants his framing of a perpetual war against al-Qaeda from 2010 with the invocation of James Madison's quote, which illustrates the danger that perpetual war poses to a democratic society. It was nevertheless in this speech that Obama legitimized the continued use of drone strikes on terrorism suspects in foreign countries, regardless of whether the United States is formally at war with that country. The persistence of this discourse on terrorism, we believe, should be considered a contributing factor for why many of the Bush-era counterterrorism policies have remained in place (e.g., extraordinary rendition; Whitlock, 2013).

We will not go so far as to make claims about President Obama's aspirations regarding U.S. counterterrorism policy or about the potential constraints imposed on his administration. What our results do illustrate, however, is the overall "naturalization" (see Fairclough, 1995) of terrorism discourse after the September 11, 2011 attacks (Jackson, 2007). Rather than being viewed as a particular ideological construct jus- 
tifying a specific type of response to the September 11 attacks, the terrorism discourse of both Bush and Obama, featuring the depiction of terrorists as an evil that must be destroyed by any means necessary, is treated as natural and commonsensical. This war-on-terrorism discourse thus forms the background knowledge from which in-group (United States and its allies) and out-group (terrorists) categories emerge (van Dijk, 2006) and counterterrorism strategy is determined.

The construction of enemies is a common feature of political discourse (see Edelman, 1988). Our findings add to a growing body of literature demonstrating the power that labeling and defining enemy groups has on determining policies toward those groups. Bhatia (2005), for instance, writes, "To name is to identify an object, remove it from the unknown, and then assign it a set of characteristics, motives, values and behaviors" (p. 8). Previous research, focusing primarily on the Bush administration, has shown how, from the war on terrorism, discourse terrorists have been identified with barbarism (Kinsella, 2005; Leudar et al., 2004) and criminality (Golec de Zavala \& Kossowska, 2011). Adding to this body of research, our results show how the figure of "terrorist" was identified with extreme moral transgression (see also Lazar \& Lazar, 2004). This type of construction served the dual purpose of delegitimizing terrorists and laying the groundwork for the justification of the U.S. counterterrorism policy (Bhatia, 2005).

Further evidence for the naturalization of the war-on-terrorism discourse throughout both presidencies is the relative support for many extreme counterterrorism policies among the public. A majority of the U.S. public support the use of drone strikes (Pew Research Center, 2013a) and view the NSA domestic surveillance program as an acceptable counterterrorism tactic (Pew Research Center, 2013b). An overwhelming majority of the U.S. public $(70 \%)$ also supports the decision to keep the prison camp at Guantanamo Bay open (Tyson, 2013). The support for these policies, despite their potential consequences for civil liberties and the rule of law, make sense when taking into account the morally abject terrorist enemy figure that lies at the center of the war-on-terrorism discourse revealed in our study.

\section{Politics at the Water's Edge: Lessons for Peace Psychology}

"To me 'bipartisan foreign policy' means a mutual effort, under our indispensable twoparty system," wrote Senator Arthur H. Vandenberg (1952), "to unite our official voice at the water's edge that America speaks with maximum authority against those who would divide and conquer us and the free world" (pp. 552-553). We referenced this oft-cited sentiment, shortened usually to the admonishment that "partisan politics should stop at the water's edge," as a potential explanation for the similarities we observed in the terrorrelated rhetoric between Presidents Bush and Obama. That is, despite President Bush and President Obama being of two different political parties - and concurrently two different political ideologies - the fact that terrorism is viewed as a foreign policy matter may account for the similarities observed in the speeches of both presidents. The need to maintain a "common front" against a national threat may also explain the ambivalence characteristic of Obama's terror-related rhetoric. Although explicitly repudiating counterterrorism measures from the Bush administration, Obama largely reproduced the war-onterrorism discourse of his predecessor.

Recent scholarship (Haidt, 2012; Lakoff, 2002) has focused on factors that distinguish people of different political orientations (namely, liberals and conservatives). The results of our study show that this focus may be too narrow. The persistence of a war-onterrorism discourse featuring, at its core, a morally excluded and delegitimized terrorist enemy figure in two presidential administrations of different political leanings is noteworthy. This discourse has provided-and continues to provide - the moral justifications for the greatest excesses and abuses of U.S. counterterrorism policy following the September 11, 2001 attacks. What is critical for peace psychologists, therefore, is to focus greater attention on those issues that seemingly transcend partisanship and to deconstruct the "background knowledge" (Fairclough, 1995) contained therein.

In analyzing the terror-related rhetoric of Presidents Bush and Obama, our study answers those who have called for the greater use of 
discursive methods in the study of peace psychology (Gibson, 2012; Hammack \& Pilecki, 2012). Such methods assume the fundamental link between mind and society with language as the primary mediating process (Hammack \& Pilecki, 2012, in press). Recognizing the influence that language backed by political power can have on how identity and reality are experienced, discursive methods are especially useful in uncovering the ideological content implicated within political rhetoric (Fairclough, 1995; Tileagă, 2013; van Dijk, 2006). Discourse methods also recognize that language is a form of social action (Edwards, 1991). As exemplified in the results of our study, language can be used specifically to construct social categories for the purposes of legitimizing specific political projects (e.g., Reicher, 2004; Reicher \& Hopkins, 2001a, 2001b). The strength of discursive methods is thus the assumption that language is not neutral, but is instead a tool toward which policies and actions-such as extreme counterterrorism measures - are framed as morally acceptable and necessary.

Our study was limited in a number of ways. First, our corpus of speeches contained only those from Presidents Bush and Obama. Other administration officials (e.g., Secretary of State, Secretary of Defense) may have employed a different rhetorical strategy when discussing terrorism. Future research should thus broaden its examination of terrorism discourse to include other administration officials as well as members of Congress. Second, we cannot make any claims regarding the effectiveness of the political rhetoric analyzed in our study. Although we part to the persistence of many counterterrorism policies, as well as some public opinion data, we cannot ascertain whether those listening to the speeches were more likely to either agree with the depiction of terrorists presented in the speeches or support certain counterterrorism measures (e.g., domestic surveillance). The purpose of this study was primarily descriptive, in that we sought to reveal how terrorism was talked about by Presidents Bush and Obama. The fact that we cannot make specific claims regarding effectiveness vis-à-vis the intended audiences should not diminish our findings. Future research, nevertheless, might incorporate an experimental component (e.g., Herrera \& Reicher, 1998; Verkuyten, 2011) that can determine the extent to which presidential rhetoric influences peoples' attitudes toward counterterrorism policy.

\section{References}

Austin, J. L. (1962). How to do things with words. New York, NY: Oxford University Press.

Bakhtin, M. M. (1981). The dialogic imagination (C. Emerson \& M. Holquist, Trans.). Austin, TX: University of Texas Press.

Bar-Tal, D. (1990). Causes and consequences of delegitimization: Models of conflict and ethnocentrism. Journal of Social Issues, 46, 65-81. doi: 10.1111/j.1540-4560.1990.tb00272.x

Bar-Tal, D., \& Hammack, P. L. (2012). Conflict, delegitimization and violence. In L. R. Tropp (Ed.), Oxford handbook of intergroup conflict (pp. 29-52). New York, NY: Oxford University Press.

Bhatia, M. V. (2005). Fighting words: Naming terrorists, bandits, rebels and other violent actors. Third World Quarterly, 26, 5-22. doi:10.1080/01436590 42000322874

Billig, M. (1985). Prejudice, categorization, and particularlization: From a perceptual to a rhetorical approach. European Journal of Social Psychology, 15, 79-103. doi:10.1002/ejsp.2420150107

Billig, M. (1996). Arguing and thinking: A rhetorical approach to social psychology (2nd ed.). Cambridge, UK: Cambridge University Press.

Billig, M. (2012). Undisciplined beginnings, academic success, and discursive psychology. British Journal of Social Psychology, 51, 413-424. doi: 10.1111/j.2044-8309.2011.02086.x

Blumer, H. (1969). Symbolic interactionism. Englewood Cliffs, NJ: Prentice Hall.

Bruner, J. (1990). Acts of meaning. Cambridge, MA: Harvard University Press.

Collet, T. (2009). Civilization and civilized in post9/11 US presidential speeches. Discourse \& Society, 20, 455-475. doi:10.1177/0957926509104023

Condor, S., Tileagă, C., \& Billig, M. (2013). Political rhetoric. In L. Huddy, D. O. Sears \& J. S. Levy (Eds.), Oxford handbook of political psychology (pp. 262-300). New York, NY: Oxford University Press.

Crawford, N. C. (2003). Just war theory and the U.S. counterterror war. Perspectives on Politics, 1, 5-25. doi:10.1017/S1537592703000021

De Castella, K., \& McGarty, C. (2011). Two leaders, two wars: A psychological analysis of fear and anger content in political rhetoric about terrorism. Analyses of Social Issues and Public Policy (ASAP), 11, 180-200. doi:10.1111/j.1530-2415 .2011.01243.x

De Castella, K., McGarty, C., \& Musgrove, L. (2009). Fear appeals in political rhetoric about terrorism: An analysis of speeches by Australian 
Prime Minister Howard. Political Psychology, 30, 1-26. doi:10.1111/j.1467-9221.2008 $.00678 . x$

Edelman, M. (1988). Constructing the political spectacle. Chicago, IL: University of Chicago Press.

Edwards, D. (1991). Categories are for talking: On the cognitive and discursive bases of categorization. Theory \& Psychology, 1, 515-542. doi:10.1177/0959 354391014007

Edwards, D., \& Potter, J. (1992). Discursive psychology. London, UK: Sage.

Esch, J. (2010). Legitimizing the "War on Terror": Political myth in official-level rhetoric. Political Psychology, 31, 357-391. doi:10.1111/j.1467-9221.2010 .00762.x

Fairclough, N. (1995). Critical discourse analysis: The critical study of language. London, UK: Longman.

Gibson, S. (2012). "I'm not a war monger but . . .": Discourse analysis and social psychological peace research. Journal of Community \& Applied Social Psychology, 22, 159-173. doi:10.1002/casp.1099

Golec de Zavala, A., \& Kossowska, M. (2011). Correspondence between images of terrorists and preferred approaches to counterterrorism: The moderating role of ideological orientations. European Journal of Social Psychology, 41, 538-549. doi: 10.1002/ejsp. 810

Graumann, C. F. (1998). Verbal discrimination: A neglected chap. in the social psychology of aggression. Journal for the Theory of Social Behaviour, 28, 41-61. doi:10.1111/1468-5914.00062

Greenwald, G. (2013a, February 5). Chilling legal memo from Obama DOJ justifies assassination of US citizens. The Guardian. Retrieved from http:// www.guardian.co.uk/commentisfree/2013/feb/05/ obama-kill-list-doj-memo

Greenwald, G. (2013b, June 5). NSA collecting phone records of millions of Verizon customers daily. The Guardian. Retrieved from http://www .guardian.co.uk/world/2013/jun/06/nsa-phonerecords-verizon-court-order

Greenwald, G., \& MacAskill, E. (2013, June 6). NSA Prism program taps in to user data of Apple, Google and others. The Guardian. Retrieved from http://www .guardian.co.uk/world/2013/jun/06/ustech-giants-nsa-data

Haidt, J. (2012). The righteous mind: Why good people are divided by politics and religion. New York, NY: Random House.

Halperin, E., Bar-Tal, D., Sharvit, K., Rosler, N., \& Raviv, A. (2010). Prolonged occupation: The psychosocial aspects of an occupying society. Journal of Peace Research, 47, 59-70. doi:10.1177/002 2343309350013

Hammack, P. L. (2010). The political psychology of personal narrative: The case of Barack Obama. Analyses of Social Issues and Public Policy
(ASAP), 10, 182-206. doi:10.1111/j.1530-2415 2010.01207.x

Hammack, P. L. (in press). Mind, story, society: The political psychology of narrative. In M. Hanne (Ed.), Warring with words: Narrative and metaphor in domestic and international politics. New York, NY: Psychology Press.

Hammack, P. L., \& Pilecki, A. (2012). Narrative as a root metaphor for political psychology. Political Psychology, 33, 75-103. doi:10.1111/j.1467-9221 .2011.00859.x

Hammack, P. L., \& Pilecki, A. (in press). Methodological approaches in political psychology: Discourse and narrative. In T. Capelos, H. Dekker, C. Kinnvall, \& P. Nesbitt-Larking (Eds.), Palgrave handbook of global political psychology. New York, NY: Palgrave Macmillan.

Hammack, P. L., \& Toolis, E. (in press). Identity, politics, and the cultural psychology of adolescence. In L. Jensen (Ed.), Oxford handbook of human development and culture. New York, NY: Oxford University Press.

Herrera, M., \& Reicher, S. (1998). Making sides and taking sides: An analysis of salient images and category constructions for pro- and anti-Gulf War respondents. European Journal of Social Psychology, 28, 981-993. doi:10.1002/(SICI)10990992(1998110)28:6<981::AID-EJSP906>3.0 .CO;2-L

Hoffman, B. (2006). Inside terrorism. New York, NY: Columbia University Press.

Jackson, R. (2005). Writing the war on terrorism: Language, politics and counter-terrorism. Manchester, UK: Manchester University Press.

Jackson, R. (2007). Language, policy and the construction of a torture culture in the war on terrorism. Review of International Studies, 33, 353-371. doi:10.1017/S0260210507007553

Kinsella, H. M. (2005). Discourse of difference: Civilians, combatants, and compliance with the laws of war. Review of International Studies, 31, 163185. doi:10.1017/S0260210505006844

Lakoff, G. (2002). Moral politics: How liberals and conservatives think (2nd ed.). Chicago, IL: University of Chicago Press. doi:10.7208/chicago/ 9780226471006.001.0001

Lazar, A., \& Lazar, M. M. (2004). The discourse of the New World Order: "Out-casting" the double face of threat. Discourse \& Society, 15, 223-242. doi:10.1177/0957926504041018

Leudar, I., Marsland, V., \& Nekvapil, J. (2004). On membership categorization: "Us," "them," and "doing violence" in political discourse. Discourse \& Society, 1, 243-266. doi:10.1177/095792650 4041019

Mayer, J. (2009). The dark side: The inside story of how the war on terror turned into a war on American ideals. New York, NY: Anchor. 
Mazzetti, M., Savage, C., \& Shane, S. (2013, March 9). How a US citizen came to be in America's cross hairs. The New York Times. Retrieved from http:// www.nytimes.com/2013/03/10/world/middleeast/ anwar-al-awlaki-a-us-citizen-in-americas-crosshairs.html

McCrisken, T. (2011). Ten years on: Obama's war on terrorism in rhetoric and practice. International Affairs, 87, 781-801. doi:10.1111/j.1468-2346 $.2011 .01004 . \mathrm{x}$

Mead, G. H. (1934). Mind, self and society. Chicago, IL: University of Chicago Press.

Miller Center. (2013a). Farewell Address to the Nation (January 15, 2009) George W. Bush. Charlottesville, VA: University of Virginia. Retrieved from http://millercenter.org/president/speeches/ detail $/ 4450$

Miller Center. (2013b). State of the Union Address (January 29, 2002) George W. Bush. Charlottesville, VA: University of Virginia. Retrieved from http://millercenter.org/president/speeches/detail/ 4540

Miller Center. (2013c). State of the Union Address (January 20, 2004) George W. Bush. Charlottesville, VA: University of Virginia. Retrieved from http://millercenter.org/president/speeches/detail/ 4542

Miller Center. (2013d). State of the Union Address (January 31, 2006) George W. Bush. Charlottesville, VA: University of Virginia. Retrieved from http://millercenter.org/president/speeches/detail/ 4461

Miller Center. (2013e). State of the Union Address (January 23, 2007) George W. Bush. Charlottesville, VA: University of Virginia. Retrieved from http://millercenter.org/president/speeches/detail/ 4455

Miller Center. (2013f). State of the Union Address (January 28, 2008) George W. Bush. Charlottesville, VA: University of Virginia. Retrieved from http://millercenter.org/president/speeches/detail/ 4454

Montiel, C. J., \& Shah, A. A. (2008). Effects of political framing and perceiver's social position on trait attributions of a terrorist/freedom fighter. Journal of Language and Social Psychology, 27, 266-275. doi:10.1177/0261927X08317951

Mullen, J. (2013, July 2). CNN exclusive: George W. Bush on AIDS, Mandela, Snowden and his legacy. Retrieved from http://www.cnn.com/2013/07/01/ politics/bush-interview/index.html

Opotow, S. (1990). Moral exclusion and injustice: An introduction. Journal of Social Issues, 46, 1-20. doi:10.1111/j.1540-4560.1990.tb00268.x

Oren, N., Rothbart, D., \& Korostelina, K. V. (2009). Striking civilian targets during the Lebanon War: A social psychological analysis of Israeli decision makers. Peace and Conflict: Journal of Peace Psy- chology, 15, 281-303. doi:10.1080/10781910903 055345

Parker, I. (1990). Discourse: Definitions and contradictions. Philosophical Psychology, 3, 187-204. doi:10.1080/09515089008572998

Pew Research Center. (2011, September 1). Ten years after 9/11: United in remembrance, divided over policies. Retrieved from http://www.people-press.org/ files/legacy-pdf/9-1-11\%20Sept.\%2011\%20Release .pdf

Pew Research Center. (2013a, February 11). Continued support for U.S. drone strikes. Retrieved from http://www .people-press.org/files/legacy-pdf/211-13\%20Drones\%20Release.pdf

Pew Research Center. (2013b, June 10). Majority views NSA phone tracking as acceptable antiterror tactic. Retrieved from http://www peoplepress.org/2013/06/10/majority-views-nsa-phonetracking-as-acceptable-anti-terror-tactic/1/

Potter, J. (1996). Representing reality: Discourse, rhetoric and social construction. Thousand Oaks, CA: Sage.

Potter, J., \& Wetherell, M. (1987). Discourse and social psychology: Beyond attitudes and behavior. Thousand Oaks, CA: Sage.

Potter, J., \& Wetherell, M. (1995). Discourse analysis. In J. A. Smith, R. Harre, \& L. van Langenhove (Eds.), Rethinking methods in psychology (pp. 8092). London, UK: Sage. doi:10.4135/97814462217 92.n6

President Bush's Speech on Terrorism. (2006, September 6). The New York Times. Retrieved from http://www.nytimes.com/2006/09/06/washington/ 06bush_transcript.html

Reicher, S. (2004). The context of social identity: Domination, resistance and change. Political Psychology, 25, 921-945. doi:10.1111/j.1467-9221 .2004.00403.x

Reicher, S., \& Hopkins, N. (1996). Self-category constructions in political rhetoric: An analysis of Thatcher's and Kinnock's speeches concerning the British miners' strike (1984-5). European Journal of Social Psychology, 26, 353-371. doi: 10.1002/(SICI) 1099-0992(199605)26:3<353:: AID-EJSP757>3.0.CO;2-O

Reicher, S., \& Hopkins, N. (2001a). Psychology and the end of history: A critique and a proposal for the psychology of social categorization. Political Psychology, 22, 383-407. doi:10.1111/0162-895X .00246

Reicher, S., \& Hopkins, N. (2001b). Self and nation. London, UK: Sage.

Sani, F., \& Reicher, S. (1998). When consensus fails: An analysis of the schism within the Italian communist party (1991). European Journal of Social Psychology, 28, 623-645. doi:10.1002/(SICI)10990992(199807/08)28:4<623::AID-EJSP885>3.0 .CO;2-G 
Sani, F., \& Reicher, S. (1999). Identity, argument and schism: Two longitudinal studies of the split in the Church of England over the ordination of women to the priesthood. Group Processes \& Intergroup Relations, 2, 279-300. doi:10.1177/13684302990 23005

Sapir, E. (1921). Language: An introduction to the study of speech. New York, NY: Harcourt, Brace.

Sowińska, A. (2013). A critical discourse approach to the analysis of values in political discourse: The example of freedom in President Bush's State of the Union addresses (2001-2008). Discourse \& Society. Advance online publication. doi:10.1177/ 0957926513486214

The White House, Office of the Press Secretary. (2007, July 24). Remarks by President Bush on the Global War on Terror. Retrieved from http:// kabul.usembassy.gov/bush_072407.html

The White House, Office of the Press Secretary. (2009a). Remarks by the President on a new beginning. Retrieved from http://www.whitehouse .gov/the_press_office/Remarks-by-the-Presidentat-Cairo-University-6-04-09

The White House, Office of the Press Secretary. (2009b). Remarks by the President on a new strategy for Afghanistan and Pakistan. Retrieved from http://www.whitehouse.gov/the-press-office/ remarks-president-a-new-strategy-afghanistanand-pakistan

The White House, Office of the Press Secretary. (2009c). Remarks by the President on national security. Retrieved from http://www.whitehouse .gov/the-press-office/remarks-president-nationalsecurity-5-21-09

The White House, Office of the Press Secretary. (2009d). Remarks by the President to the nation on the way forward in Afghanistan and Pakistan. Retrieved from http://www.whitehouse.gov/thepress-office/remarks-president-address-nationway-forward-afghanistan-and-pakistan

The White House, Office of the Press Secretary. (2011). Remarks by the President on the Middle East and North Africa. Retrieved from http://www .whitehouse.gov/the-press-office/2011/05/19/ remarks-president-middle-east-and-north-africa $\% 20$

The White House, Office of the Press Secretary. (2013a). Remarks by the President at the National Defense University. Retrieved from http://www .whitehouse.gov/the-press-office/2013/05/23/ remarks-president-national-defense-university
The White House, Office of the Press Secretary. (2013b). Statement by the President. Retrieved from http://www.whitehouse.gov/the-press-office/ 2013/06/07/statement-president

Tileagă, C. (2005). Accounting for extreme prejudice and legitimating blame in talk about the Romanies. Discourse \& Society, 16, 603-624. doi:10.1177/ 0957926505054938

Tileagă, C. (2006). Representing the "other": A discursive analysis of prejudice and moral exclusion in talk about Romanies. Journal of Community \& Applied Social Psychology, 16, 19-41. doi:10.1002/casp.846

Tileagă, C. (2007). Ideologies of moral exclusion: A critical discourse reframing of depersonalization, delegitimization and dehumanization. British Journal of Social Psychology, 46, 717-737. doi:10.1348/ $014466607 X 186894$

Tileagă, C. (2013). Political psychology: Critical perspectives. New York, NY: Cambridge University Press

Tyson, A. (2013, May 29). Should Guantanamo be open or closed? Either way, Democrats have stuck with Obama. Retrieved from http://www.pewresearch.org/ fact-tank/2013/05/29/should-guantanamo-be-open-orclosed-either-way-democrats-have-stuck-with-obama/

Vandenberg, A. H. (1952). The private papers of Senator Vandenberg. Boston, MA: Houghton Mifflin.

van Dijk, T. A. (2006). Ideology and discourse analysis. Journal of Political Ideologies, 11, 115-140. doi:10.1080/13569310600687908

Verkuyten, M. (2011). Justifying discrimination against Muslim immigrants: Out-group ideology and the five-step social identity model. British Journal of Social Psychology, 52, 345-360. doi:10.1111/j.20448309.2011.02081.x

Volosinov, V. N. (1929/1973). Marxism and the philosophy of language (L. Matejka \& I. R. Titunik, Trans.). Cambridge, MA: Harvard University Press.

Vygotsky, L. S. (1934/1962). Thought and language (E. Hanfmann \& G. Vakar, Trans.). Cambridge, MA: MIT Press.

Whitlock, C. (2013, January 1). Renditions continue under Obama, despite due-process concerns. The Washington Post. Retrieved from http://articles.washingtonpost.com/ 2013-01-01/world/36323571_1_obama-administrationinterrogation-drone-strikes

Whorf, B. L. (1956). Language, thought, and reality: Selected writings. Cambridge, MA: MIT Press. 